\title{
Vet en gezondheid, een kwestie van flexibiliteit
}

\author{
Citation for published version (APA):
}

Blaak, E. E. (2007). Vet en gezondheid, een kwestie van flexibiliteit. Maastricht University. https://doi.org/10.26481/spe.20071005eb

Document status and date:

Published: 05/10/2007

DOI:

10.26481/spe.20071005eb

Document Version:

Publisher's PDF, also known as Version of record

\section{Please check the document version of this publication:}

- A submitted manuscript is the version of the article upon submission and before peer-review. There can be important differences between the submitted version and the official published version of record.

People interested in the research are advised to contact the author for the final version of the publication, or visit the DOI to the publisher's website.

- The final author version and the galley proof are versions of the publication after peer review.

- The final published version features the final layout of the paper including the volume, issue and page numbers.

Link to publication

\footnotetext{
General rights Owners
rights.

- You may freely distribute the URL identifying the publication in the public portal. please follow below link for the End User Agreement:

www.umlib.nl/taverne-license

Take down policy

If you believe that this document breaches copyright please contact us at:

repository@maastrichtuniversity.nl

providing details and we will investigate your claim.
}

Copyright and moral rights for the publications made accessible in the public portal are retained by the authors and/or other copyright owners and it is a condition of accessing publications that users recognise and abide by the legal requirements associated with these

- Users may download and print one copy of any publication from the public portal for the purpose of private study or research.

- You may not further distribute the material or use it for any profit-making activity or commercial gain

If the publication is distributed under the terms of Article $25 \mathrm{fa}$ of the Dutch Copyright Act, indicated by the "Taverne" license above, 
Vet en gezondheid, een kwestie van flexibiliteit 


\section{Colofon}

Ontwerp en print: Océ Business Services, Maastricht

ISBN: 978-90-5681-272-O

NUR: 870

Alle rechten voorbehouden. Niets uit deze uitgave mag worden verveelvoudigd, opgeslagen in een geautomatiseerd gegevensbestand of openbaar gemaakt worden, zonder voorafgaande schriftelijke toestemming van de auteur of uitgever. 


\section{Vet en gezondheid, een kwestie van flexibiliteit}

\section{Rede}

Uitgesproken bij de aanvaarding van het ambt van

profileringshoogleraar Fysiologie van het vetmetabolisme aan de Faculty of Health, Medicine and Life Sciences

Op vrijdag 5 oktober 2007

door

Prof dr Ellen E Blaak

Universiteit Maastricht 

Mijnheer de Rector Magnificus, dames en heren,

\section{Inleiding}

In de komende 3 kwartier ga ik $u$ vertellen over vet in relatie tot gezondheid. Ik wil ingaan op hoe de stofwisseling van vetten wordt gestuurd oftewel gereguleerd en wat er gebeurt als deze regulering niet goed werkt.

Om te leven moeten we eten. Wij nemen onze dagelijkse voeding tot ons in de vorm van maaltijden die voor het grootste deel uit vetten en koolhydraten bestaan. Ons lichaam heeft van origine een flexibel en nauwgezet regelsysteem dat onze stofwisseling goed aanpast aan deze niet continue toevoer van voedsel, dit voedsel opslaat in de lichaamsenergievoorrraden en weer vrijmaakt als er behoefte is aan energie, bijvoorbeeld bij een verhoogde lichamelijke aktiviteit.

De laatste decennia is onze leefomgeving duidelijk veranderd. De trend is van het 'eten om te leven' meer verschoven in de richting van 'leven om te eten'. Voeding is op steeds meer verkooppunten, in grote hoeveelheden en met steeds meer variatie te verkrijgen. Tegelijkertijd is ook de koopkracht van de bevolking gegroeid en daarmee is de meeste voeding ook voor de meesten financieel bereikbaar. Mensen kijken meer televisie en zitten vaker achter de computer, wat gepaard gaat met inactiviteit.

Kortom, onze moderne leefstijl met een voeding relatief rijk in energie en verzadigde vetten en een laag nivo van lichamelijke aktiviteit doet een groot beroep op de flexibiliteit van onze stofwisseling. Deze flexibilteit kan sterk varieren tussen mensen. Zo zal de consumptie van bitterballen tijdens de receptie na deze rede bij de een tot een relatief hoge verbranding van vetten leiden terwijl bij de ander meer vet wordt opgeslagen in het lichaam of er een hoog nivo van vetten in het bloed blijft. Een hoge opslag van vet en een hoog nivo van vetten in het bloed kan als deze voortduren uiteindelijk tot ziekte leiden, zoals vetzucht of obesitas en type 2 diabetes mellitus (in de volksmond ouderdomssuikerziekte), maar hier kom ik later nog op terug. In die zin is de relatie tussen vet en gezondheid, een kwestie van flexibiliteit. 
Mijn fascinatie voor vet is eigenlijk al begonnen tijdens mijn studie Humane Voeding aan de Landbouwuniversiteit Wageningen. Tijdens mijn stageperiode in het Engelse Cambridge heb ik mij bezig gehouden met de vetstofwisseling van de spieren bij obesitas, een gebied wat mij toen al boeide. Toen ik daarna een advertentie zag voor een AlO specifiek op dit gebied moest ik daar wel op solliciteren. Zo gezegd zo gedaan. In 1989 ben ik begonnen als assistent-in-opleiding bij de vakgroep Humane Biologie van de Universiteit Maastricht. De reden waarom ik dit wat uitgebreider recapituleer is dat hier 'flexibiliiteit' al een belangrijke rol heeft gespeeld als basis voor mijn onderzoekslijn 'vet en gezondheid', zei het in een wat andere context. Na mijn sollicitatie gesprek was het de bedoeling dat ik met onmiddellijke ingang zou beginnen. In Maastricht gearriveerd, voorlopig nog zonder woonruimte, ging mijn eerste onderzoek de $2^{\text {de }}$ dag van mijn aanstelling van start. Het interessante project en de fijne collega's hebben deze flexibele start natuurlijk ruimschoots gecompenseerd.

In mijn AlO-onderzoek stond de vetstofwisseling al centraal met name gericht op het ontstaan van obesitas. Afgewisseld met enkele buitenlandbezoeken ben ik in Maastricht gebleven en heeft vet altijd centraal gestaan in mijn onderzoek zei het in een latere fase meer gericht op de ziekten die geassocieerd zijn met obesitas zoals type 2 diabetes mellitus. Nu, bijna 20 jaar later zult u zich mogelijk afvragen of inmiddels alles al bekend is. Het antwoord op deze vraag is nee. We kennen nog lang niet alle factoren die een rol spelen bij de regulering van de stofwisseling bij de gezonde mens, laat staan wat er gebeurt als er iets fout gaat en dit leidt tot ziekte.

Ik ga vanmiddag een overzicht geven van hoe het onderzoek en onderwijs binnen mijn leerstoel gestalte krijgen aan de hand van voorbeelden van de werkvloer. Het geheel van aktiviteiten is te breed om een volledig overzicht in 45 minuten te presenteren. I $\mathrm{k}$ wil $\mathrm{u}$ met name een indruk geven waarvoor ik hier sta. Ik wil niet pretenderen dat dit de enige visie op vet is of dat wij de enigen zijn die onderzoek op dit gebied doen, velen anderen doen dit ook. Tenslotte hoop ik $u$ iets van mijn gedrevenheid en fascinatie voor vet over te kunnen brengen. 


\section{Fysiologie van het vetmetabolisme}

Om te beginnen wil ik mijn werkterrein nader definieren.

Kort gezegd houdt de fysiologie zich bezig met het functioneren van het lichaam en lichaamsfuncties. Het gebied van de fysiologie van de vetstofwisseling beslaat het gebied van de opname en vertering van voedingsvetten, het transport in het lichaam, en de opslag, verbranding en vrijmaking van vetten.

De grootste hoeveelheid van ons lichaamsvet (>95\%) is opgeslagen in ons vetweefsel in de vorm van triglyceriden, wat esters zijn van glycerol en vetzuren, maar kleine opslag depots zijn ook aanwezig in onze lever en onze spieren. Als er geen voeding opgenomen wordt, tijdens gevaste omstandigheden, worden vetzuren vrijgemaakt vanuit de triglyceriden in ons vetweefsel, in een proces wat lipolyse genoemd wordt. Via het bloed worden deze vetzuren vervoerd naar weefsels die ze als brandstof gebruiken, de skeletspieren, ons hart en de lever. Met name onze skeletspieren zijn belangrijk bij de verwijdering van vetzuren uit de bloedbaan aangezien ze $40 \%$ van onze lichaamsmassa zijn. Voedingsvet dat via de darm binnenkomt wordt naar de weefsels getransporteerd, terwijl tegelijkertijd het vrijmaken van vetten door insuline vanuit de pancreas wordt onderdrukt. Vetten zijn niet alleen een energiebron maar kunnen ook een belangrijke regulerende rol in de stofwisseling spelen. Hier kom ik later nog op terug.

Ons onderzoek richt zich met name op hoe ons lichaam met vet en de verschillende vetten in de voeding omgaat, hoe een teveel aan vet in de vetvoorraden, in het bloed en in andere weefsels zoals spier en lever ontstaat en gehandhaafd wordt en waarom een teveel aan vet een verhoogd risico op obesitas en diabetes kan geven. Ik hoop dat $u$, uit dit overzicht duidelijk is dat met name de wisselwerking tussen de verschillende organen van belang is. Belangrijk aandachtspunt voor ons hierbij is de wisselwerking tussen vetweefsel en spier. Maar er is natuurlijk meer. In onze studies houden we ook rekening met andere organen zoals de pancreas, de darm, de lever en hersenen. Zo begint al een beetje meer het plaatje van een mens te ontstaan. 


\section{De definitie van stofwisseling}

Globaal heb ik $u$ nu geschetst wat mijn werkterrein behelst, de fysiologie in de context van de vetstofwisseling. Nu wil ik vervolgens de term stofwisseling oftewel metabolisme nader definieren. In de Dikke van Dale wordt dit gedefinieerd als: ' het geheel van biochemische processen die in levende organismen plaatsvinden'.

Er kunnen in de cel wel 15000 verschillende chemische reacties plaatsvinden Voor elke reactie is een enzym nodig dat op een bepaalde plaats in een bepaalde cel van een bepaald orgaan aanwezig moet zijn. Als we ons dan ook nog realiseren dat al deze cellen met elkaar moeten communiceren om tot een functie van een weefsel of orgaan te komen en dat tussen de weefsels en organen zoals bijvoorbeeld het vetweefsel en de spier weer stoffen getransporteerd moeten worden, die dan via specifieke opname systemen weer door de cellen opgenomen moeten worden, geeft dit een goed beeld over hoe complex ons metabolisme is.

De karakterisering van het menselijk erfelijk materiaal, onze genen oftewel DNA eind vorige eeuw is de basis geweest voor stormachtige ontwikkelingen binnen het veld van de moleculaire biologie. Dit heeft veel waardevolle informatie opgeleverd over de moleculaire basis van leven. Dit heeft ook tot een tegenstrijdige situatie geleid in het biomedisch onderzoek, die ik aan de hand van de hand van een bekende Indische gelijkenis wil typeren:

\section{Cautionary tale}

"It was six men of Indostan

To learning much inclined

Who went to see the Elephant

(though all of them were blind),

That each by observation

Might satisfy his mind

......each was partly in the right

And all were in the wrong" 


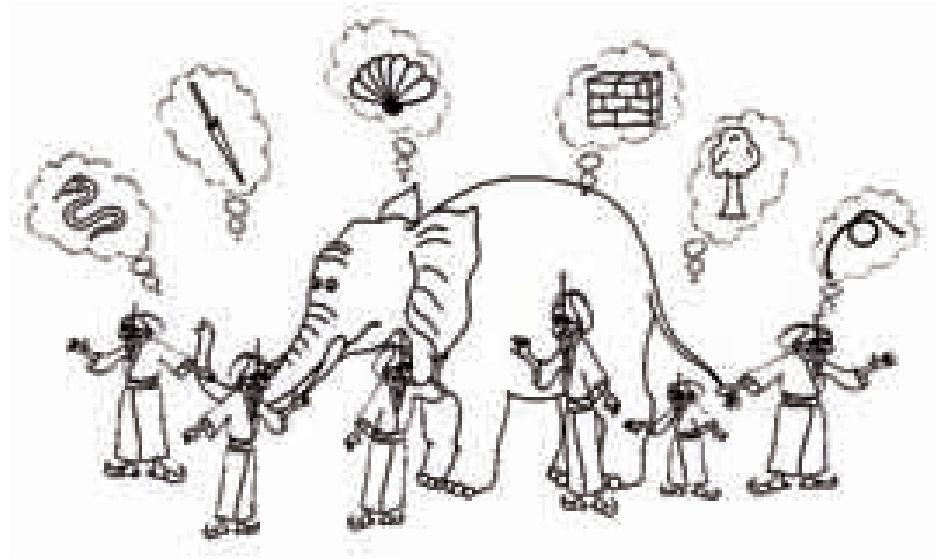

Fig 1: The cautionary tale [1]

Arme olifant; deze zal zo nooit gevonden worden. De olifant ziet er niet uit als een muur, een boom, een touw, een slang of een speer en ze zullen hem nooit kunnen zien, maar mogelijk als ze de delen samengevoegd en uitgewisseld hadden was een abstract idee onstaan van hoe die olifant eruit zou zien.

Vertaald naar het biomedisch onderzoek, is zoals gezegd onze kennis van onderdelen van het lichaam spectaculair toegenomen. Dit heeft echter maar in beperkte mate geleid tot een beter begrip van het totale complexe lichaam. De kracht moet liggen in samenwerking over de grenzen van disciplines heen om het totale plaatje te krijgen.

Laat me dit wat nader uitdiepen

Onze erfelijke informatie ligt vast in ons DNA. Ons DNA is voor iedere cel hetzelfde. Toch zien niet alle cellen er hetzelfde uit. Een vetcel zal totaal verschillend zijn van een spier of levercel, Dit wordt veroorzaakt door het feit dat in elke cel weer verschillende genen worden afgelezen in de vorm van kleine afdrukken: het RNA. Het RNA treedt als tussenpersoon op om ons DNA te vertalen naar eiwitten. Nadat het RNA de celkern verlaten heeft wordt het gegrepen door grote eiwitmachines die ribosomen worden genoemd. Deze ribosomen lezen de RNA-boodschap af zoals een laser een streepjescode afleest, resulterend in een nieuw eiwit wat stap voor stap wordt opgebouwd. Dit eiwit kan bijvoorbeeld een enzym 
zijn wat betrokken is bij al die biochemische reacties die ik $u$ heb laten zien wat zal resulteren in een bepaald reactieproduct maar het kan bijvoorbeeld ook een transporter zijn die vetzuren over de celmembraan van vetweefsel of spier transporteert, die zal bewerkstelligen dat de concentratie van vetzuren in vetweefsel en spier verandert. Op al deze nivo's kan regulering van stappen plaatsvinden, maar in de hoeverre een bepaalde stap cruciaal is voor het functioneren van systeem, vereist kennis over het functioneren van het totale lichaam. Juist deze kennis ontbreekt vaak.

Wel kunnen we tegenwoordig op meerdere nivo's ons metabolisme bestuderen. Het is nu heel gebruikelijk om in een stukje weefsel van een persoon te meten of de concentratie van een gen of een product van dat gen, een eiwit, veranderd is. We moeten ons wel blijven realiseren dat veranderingen in RNA of eiwitten slechts in beperkte mate voorspellend zijn voor veranderingen in de stofwisseling. Daarvoor zijn de netwerken van stofwisselingsroutes die we bestuderen veel te complex en vertonen ze een veel te grote mate van interactie. Hoe komen we dan wel aan de informatie om te begrijpen hoe onze stofwisseling wordt gereguleerd en wat er mis gaat bij ziekte? Om dit te weten te komen zijn in het humaan fysiologisch onderzoek technieken beschikbaar gekomen om de route van metabolieten, de flux, in kaart te brengen. Hier hebben we in Maastricht alle faciliteiten voor. Later zal ik dit verder illustreren. Op het moment is het voldoende als u weet dat we hiervoor gebruik maken van stabiele isotopen, waarbij als het ware een vlaggetje wordt gehangen aan het te bestuderen molecuul. Hierdoor kunnen we de route van het molecuul door weefsels of door het lichaam volgen. Dus met het meten van fluxen in metabole systemen wordt de dynamiek van een systeem in kaart gebracht en niet de statische concentratie; dit verhoudt zich tot elkaar als een film in relatie tot een foto. Binnen ons onderzoek is het meten van fluxen door het lichaam maar ook door weefsels als het vetweefsel en de spier een belangrijk aandachtspunt. Dit alleen is echter niet voldoende. Deze kennis wordt geintegreerd met het ophelderen van onderliggende processen met moleculair biologische technieken.

\section{Genen en Leefstijl}

Obesitas, oftewel vetzucht is een groot gezondheidsprobleem wereldwijd. Meer dan de helft van de bevolking in Europa heeft 
overgewicht en gemiddeld $15 \%$ hiervan heeft obesitas. Obesitas is een belangrijke risicofactor voor de ontwikkeling van type 2 diabetes mellitus: $60-75 \%$ van het ontstaan van type 2 diabetes kan hierdoor verklaard worden. Wereldwijd is de schatting dat van 2000 tot 2030 het aantal mensen met diabetes met $40 \%$ toe zal nemen [2]. Zowel obesitas als diabetes geven een sterk verhoogd risico op hart- en vaatziekten. Dit risico is 3-4 keer hoger bij diabeten dan in de rest van de populatie. Deze trend is bijzonder alarmerend omdat hetzelfde patroon bij kinderen en adolescenten is waar te nemen.

Wat kan nu deze toename in prevalentie verklaren?

Wij zijn allen het resultaat van een continue wisselwerking tussen onze genen en onze omgeving. De genetische aanpassing op onze omgeving verloopt zeer langzaam en loopt ten minste 25000 jaar achter op veranderingen in de leefomgeving. Kortom, ons genetisch profiel is nauwelijks veranderd sinds het stenen tijdperk, toen we jagers, vissers en verzamelaars van eieren, noten, groenten, vruchten en bonen waren. Het leefpatroon van onze prehistorische voorouders werd gekenmerkt door een veel hoger nivo van lichamelijke aktiviteit, nodig om hun dagelijkse voeding bijeen te scharrelen. Op basis hiervan hebben wij een genetisch profiel ontwikkeld, wat met name op voedselopslag gericht is en dat ons hielp te overleven onder primitieve leefomstandigheden waarin perioden van voedselovervloed afgewisseld werden door perioden van voedselschaarste.

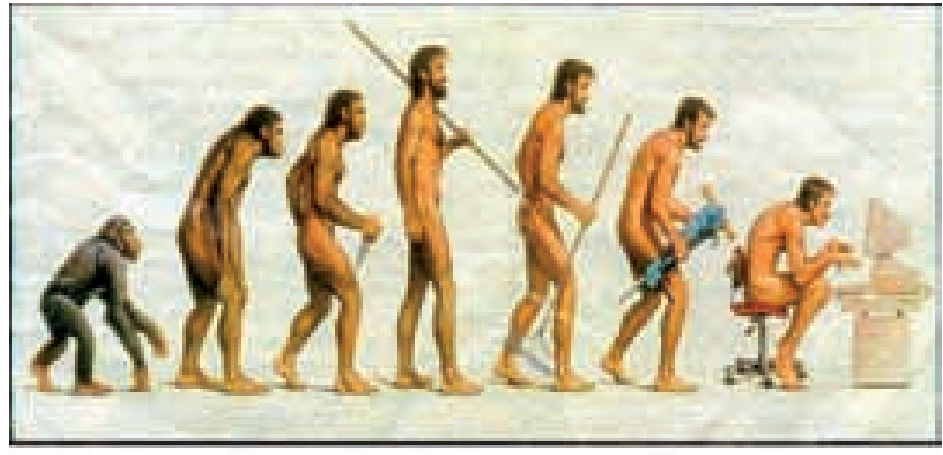

Somewhere, something went terribly wrong

Fig 2: Somewhere, something went terribly wrong 
Een veelgehoorde hypothese is dat een dysbalans tussen ons genetisch profiel met spaarzame genen en onze huidige leefstijl, een belangrijke oorzaak is voor de ontwikkeling van ziekten als obesitas, diabetes en hart- en vaatziekten [3] [4]. Kortom, onze 'inflexibele' genen bieden velen ons niet de mogelijkeid om in balans te komen met onze huidige leefstijl.

Een consequentie van deze beschrijving zou kunnen zijn dat om metabole ziekten te voorkomen onze leefstijl meer moet gaan lijken op die van onze voorouders. In het navolgende wil ik de verstoorde flexibiliteit van de stofwisseling toelichten aan de hand van voorbeelden uit ons onderzoek en ook de vraag aan de orde stellen of een verandering in leefstijl de metabole flexibiliteit kan verbeteren en zo het ontstaan van ziekte kan voorkomen.

Maar eerst nog even dit...

De vraag is of op de zeer lange termijn ons genetisch profiel zich aan zal passen aan onze moderne leefstijl. Deze aanpassing aan een hoog energie dieet gebeurt wel bij insecten, die als gevolg van een voeding met veel energie en koolhydraten, na 8 generaties, mechanismen ontwikkelen die de opslag van vet beperken [5], maar hier kunnen wij niet op wachten: de toename in prevalentie van obesitas en diabetes vereist onmiddellijke actie.

\section{Obesitas}

Obesitas is altijd het resultaat van een positieve energiebalans, waarbij de inneming van energie hoger is dan het verbuik ervan en de overmaat wordt opgeslagen in de vorm van vet. Verstoringen in de capaciteit om vetten te verbranden kunnen het risico op obesitas verhogen omdat ze een positieve energiebalans bevorderen, met name als er veel vet in de voeding zit.

Wij hebben daarom binnen de Europese multicenter studie NUGENOB onderzocht of de flexibiliteit om de vetverbranding te verhogen verstoord is bij obesitas [6]. In totaal werden 800 obese personen verdeeld over de verschillende Europese centra bestudeerd. Alle personen kregen hiervoor een milkshake die voor 95\% uit vet bestond. We zagen dat de vetverbranding na de milkshake afnam met 
toenemend lichaamsvet. In samenwerking met een aantal genetische laboratoria in Europa werd gekeken of het genetisch profiel deze lage vetverbranding zou kunnen verklaren. In totaal werd gekeken naar 42 verstoringen in de DNA-lettervolgorde (oftwel SNPs) in 26 genen. SNPs in 8 genen betrokken bij vetzuuropname, verbranding, en het vrijmaken van vet bleken onafhankelijk gerelateerd met de lage vetverbranding. De data geven aan dat bij mensen met obesitas de verstoorde vetverbranding een erfelijk bepaalde factor kan zijn. Opgemerkt moet worden dat niet alle mensen met obesitas deze lage vetverbranding vertoonden, maar ongeveer $30 \%$ van de totale groep.

Volgt hieruit dat het eten van minder vet een krachtige remedie tegen obesitas is, aangezien dit minder beroep doet op het lichaam om de vetverbranding aan te passen? Op basis van de resultaten van 16 studies werd geschat dat het verlagen van het energiepercentage vet in de voeding met $10 \%$ zou leiden tot een gewichtsverlies van 4.4 $\mathrm{kg}$ [7]. Wij onderzochten het effect van de hoeveelheid vet in de voeding op gewichtsverlies binnen de eerder genoemde NUGENOB studie gedurende een periode van $12 \mathrm{wk}$. In totaal volgden de 800 mensen met obesitas een energiebeperkt dieet met een hoge hoeveelheid vet $(45 \%$ van de totale energie-inname) of een lage hoeveelheid vet ( $25 \%$ van de totale energie-inname). Het gemiddelde gewichtsverlies was niet verschillend tussen beide groepen en was bij beide groepen $7 \mathrm{~kg}$. Een voeding met veel vet bleek met name niet gunstig voor mensen met een lage vetverbranding die op deze voeding minder gewicht verloren dan goede vetverbranders. Op de voeding met een laag percentage vet waren er geen verschillen. Dit illustreert eens te meer dat voor een aanzienlijk aantal mensen met obesitas een voeding met weinig vet een goede optie is om overtollig lichaamsvet kwijt te raken.

Tegenwoordig kunnen we ons hele erfelijke materiaal screenen om te kijken welke verstoringen gerelateerd zijn met het ontstaan van obesitas of diabetes. De verwachting is dat aan deze ziekten vele genen een klein beetje bijdragen. Tot nu toe leveren deze analyses weinig genen op [8] [9]; dit kan mogelijk verklaard worden omdat mensen met obesitas of diabetes een te heterogene groep zijn en we om werkelijk wat te weten te komen, ons moeten richten op een meer gedetaillerde karakterisering van de stofwisseling en leefstijlomstandigheden in grote groepen mensen. Dit is makkelijker gezegd dan gedaan en kan alleen bereikt worden door een bundeling van krachten over stads- en landsgrenzen heen. 


\section{Vet, obesitas en diabetes}

Type 2 diabetes mellitus is een stofwisselingsziekte. Het lichaam is niet meer in staat zelfstandig suikers oftewel glucose uit de voeding te verwerken. Het hormoon insuline, wat zorgt voor de opname van glucose in de weefsels, speelt hierbij een centrale rol. Bij de ontwikkeling van diabetes spelen verstoringen in de aanmaak en werking van het hormoon insuline (ook wel insuline resistentie genoemd) een belangrijke rol. Obesitas is de belangrijke risicofactor voor het ontwikkelen van type 2 diabetes mellitus, maar wat is nu de link tussen beide?

Normaal heeft vetweefsel een belangrijke rol als buffer voor vetzuren en worden vetzuren voor een groot deel na een maaltijd hier opgenomen. De flexibiliteit van vetweefsel om vetten op te nemen raakt verstoord als onze vetmassa en vetcellen groter worden, zoals bij vetzucht of obesitas. De vetcellen die dan vol zitten met vet kunnen nauwelijks nog extra vet opnemen en vet hoopt zich op in de bloedbaan. Dit geeft een verhoogde toevoer van vet naar andere weefsels zoals de spier en de lever.

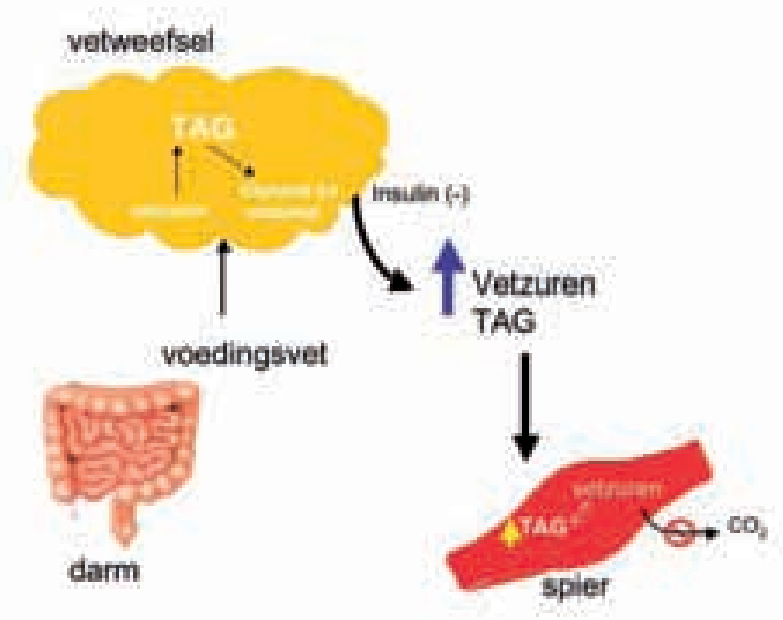

Fig 3: Van obesitas naar diabetes

Een verstoorde vetweefselfunctie geeft aanleiding tot ophoping van vetzuren en triglyceriden (TAG) in het bloed. Een verhoogde toevoer van 
vet richting de spier tezamen met een verstoorde capaciteit van de spier om vet te verbranden geeft aanleiding tot een verhoogde vetopslag. Dit kan de celfunctie verstoren en insuline resistentie induceren.

Er is steeds meer bewijs gekomen dat daarnaast de vetverbranding in de skeletspier verlaagd is bij diabetes [10] [11]. Ons onderzoek heeft hier in aanzienlijke mate aan bijgedragen [12] [13] [14] [15]. Deze metabole inflexibiliteit van de vetverbranding tezamen met een verhoogde toevoer van vetten uit het bloed kan leiden tot een ophoping van vet in de spier. Deze vetten kunnen de werking van het hormoon insuline remmen en insuline resistentie veroorzaken en het risico op diabetes verhogen. Zoals eerder aangegeven doen wij onderzoek naar de oorzaken voor een teveel aan vet in vetweefsel, in het bloed en in de spieren door de verstoorde flexibiliteit van de stofwisseling te verbinden met moleculair biologisch onderzoek naar de onderliggende mechanismen.

\section{Naar welke aspecten kijken we specifiek?}

Het vrijmaken van vetten

Allereerst zijn we geinteresseerd in de rol van het sympathische zenuwstel. Dit deel van het zenuwstelsel, dat de onwillekeurige organen bestuurt, speelt een belangrijke rol bij het vrijmaken van vetten vanuit vetweefsel. Tijdens mijn promotieonderzoek [16] en post-doc project [17] werd aangetoond dat zowel obesitas als diabetes gepaard gaan met een verlaagde capaciteit om vetten vrij te maken tijdens verhoogde sympathische aktiviteit. Dit kan een risicofactor zijn voor het ontstaan en handhaven van grote vetvoorraden. In een latere fase werd dit nader uitgediept binnnen een NWO subsidie in het Aspasia programma. Onderzoek van Johan Jocken toonde aan dat in ons lichaam met name het vet dat onderhuids op onze buik zit verantwoordelijk is voor deze verstoorde lipolyse. De regulering van lipolyse in vetweefsel maar ook in de spier wordt verder uitgediept in samenwerking met de groep van Peter Arner van het Karolinska Institute. Met name vinden we de enzymen betrokken bij de afbraak van vet: hormoon sensitief lipase (HSL) alswel het recent ontdekte adipose TriGlyceride lipase (ATGL) interessant $[18,19]$. 
De flux van vetten

Een belangrijk aandachtspunt binnen ons onderzoek is ook om de flux, de metabole route van vetten in kaart te brengen.

We weten dat een verhoogde concentratie van vetten in ons bloed na een maaltijd een risicofactor is voor de ontwikkeling van insuline resistentie. Alleen het meten van de verhoogde vetconcentratie door het afnemen van een bloedmonster geeft geen inzicht in de onderliggende oorzaak: we weten immers niet waar deze vetten vandaan komen: vanuit de voeding of vanuit het vetweefsel? Voor het meten van de route kunnen we gebruik maken van stabiele isotopen, waarbij als het ware een vlaggetje gehangen wordt aan het te bestuderen molecuul. Deze isotopen hebben dezelfde karakteristieken als het te bestuderen molecuul maar hebben een iets hoger gewicht.

We kunnen vetzuren met het ene vlaggetje via de voeding toedienen en een vetzuren met een ander vlaggetje via een infuus in de bloedbaan brengen. Door de hoeveelheid van de verschillende vlaggetjes in de vetten in het bloed te bepalen zien we welk type vetzuur bijdraagt aan de hoge vet concentratie in het bloed [20]. Om een nog completer beeld te krijgen kunnen we deze route ook meten op nivo van vetweefsel en spier, waarbij concentraties van (gelabelde) vetten in bloed wat naar de weefsels toestroomt en wat van de weefsels afkomt worden bepaald. Daarnaast kunnen we door het afnemen van een vet of spierbiopt bepalen hoeveel van de gelabelde vetzuren in de weefsels wordt ingebouwd en wat de onderliggende moleculaire verstoringen zijn. Ook wordt met studies in geisoleerde spiercellen de verminderde vetverbranding van de spier nader gekarakteriseerd, wat binnen het post-doc traject van Eva Corpeleijn wordt geinitieerd.

\section{Vetweefsel als endocrien orgaan}

Daarnaast is het een relatief nieuw inzicht dat vetweefsel een actief orgaan is, dat signaalstoffen en hormonen af kan geven. Baanbrekend hierbij was de ontdekking van het hormoon leptine dat door vetweefsel afgegeven wordt in 1994 [21]. Leptine heeft een controlerende rol in de hoeveelheid die gegeten wordt en kan daarnaast ook effecten op de stofwisseling hebben. Op basis van de resultaten in muizen studies, werd dit hormoon door velen gezien als een veelbelovend middel om overgewicht bij de mens tegen te gaan. Tot nu toe heeft het de verwachtingen op dit gebied niet waargemaakt. Wel is deze ontdekking 
een belangrijke doorbraak geweest in de imago verandering van ons vetweefsel van een saai opslagdepot naar een actief metabool orgaan.

Sindsdien zijn 10-tallen signaalstoffen, oftewel adipokines, geidentificeerd die signalen afgeven aan de rest van het lichaam en zo een rol spelen bij de stofwisseling. 'Vette' vetcellen-zoals bij obesitas- geven een ander signaal af dan 'dunne' vetcellen. De toekomst moet uitwijzen of deze endocriene stoffen (adipokines) een belangrijke rol spelen bij de verstoringen in vetstofwisseling en de ontwikkeling van diabetes en hoe die verstoorde afgifte van adipokines in vette vetcellen precies ontstaat. Dit is een lijn die voortgezet gaat worden in het post-doc project van Gijs Goossens. Hierbij moet ik tenslotte nog vermelden dat niet alle vet hetzelfde is. Afhankelijk van waar het vet gelokaliseerd is in het lichaam kan de stofwisseling verschillen. Zo is bekend dat het onderhuidse vet met name belangrijk is bij de opslag van overtollige vetzuren na een maaltijd. Hier zal ik daar nu niet verder op ingaan.

\section{Is een weg terug?}

Moeten wij terug naar de leefstijl van onze voorouders? Waarin verschilt de prehistorische voeding dan van de huidige, is de vraag. De gegevens hierover uit het verleden en onderzoek bij bevolkinsgroepen die tot voor kort nog als jager-verzamelaar leefden, tonen aan dat er ook vroeger evenals nu een grote bijdrage van dierlijk voedsel was, met een vergelijkbare hoeveelheid vet als in onze hedendaagse voeding, relatief weinig koolhydraten en veel eiwit [22]. Er is echter wel een belangrijk verschil in de kwaliteit van vetten geconsumeerd. Het vlees van de in het wild levende dieren (zowel zoogdieren als vogels en vissen) bevat namelijk veel meer lange-keten, meervoudig onverzadigde vetzuren, dan vlees van de tegenwoordige gekweekte varkers, koeien, kippen en vissen $[23,24]$. Andere belangrijke karakteristieken van het jager-verzamelaar dieet zijn: een hoge inname van vezels, antioxidanten en vitaminen, een lage natrum inname en de afwezigheid van stress en roken.

De eerste vraag is dus of metabole inflexibiliteit verbeterd kan worden door een verandering van het type vet in de voeding. De tweede vraag of een verandering in leefstijl die zowel voeding als lichamelijke aktviteit betreft diabetes kan voorkomen. 


\section{Zijn alle vetten hetzelfde?}

De eerste vraag onderzoeken we binnen het Europese project LIPGENE binnen het AIO project van Anneke van Hees.

Obesitas gaat gepaard met een verhoogd risico op diabetes en harten vaatziekten. Deze clustering van risicofactoren wordt ook wel het metabool syndroom genoemd, bestaande uit een combinatie van veel lichaamsvet op de buik, insuline resistentie, hoge nivo's van bloedsuiker, een hoge bloeddruk en abnormale bloed lipiden. We onderzoeken hoe de hoeveelheid en het type vet in onze voeding invloed heeft op de insuline resistentie, de vetstofwisseling en andere risicofactoren van het metabool syndroom.

We zijn daarnaast geinteresseerd in hoe het type vet in de voeding effect kan hebben op onze stofwisseling. Vetten leveren niet alleen energie; ze kunnen ook een belangrijke regelende rol in hun eigen stofwisseling spelen via het beinvloeden van onze genen. Het systeem werkt via DNA bindende eiwitten, de zogenaamde transcriptiefactoren die in staat zijn de expressie van genen te moduleren als ze zelf geactiveerd worden door bijvoorbeeld vetten. Het algemene principe hierbij is dat de transcriptiefactor juist deze genen aanzet die ervoor zorgen dat de concentratie van desbetreffend molecuul verlaagd wordt. Zo kunnen meervoudig onverzadigde vetzuren de peroxisome proliferators-activated receptors, de PPARs stimuleren, behorend tot de klasse van nucleaire receptoren. Op deze manier kan de expressie van genen betrokken bij de vetstofwisseling beinvloed worden en mogelijk de vetverbranding in de spier gestimuleerd kunnen worden.

Door dit effect van vetten en andere voedingsstoffen op de expressie van onze genen komt het gezegde 'Je bent wat je eet' in een heel ander daglicht te staan.

\section{Leefstijl interventie}

Leefstijl interventie, waardoor ons leefpatroon iets meer op dat van onze voorouders gaat lijken kan diabetes voorkomen. Dit hebben grote studies in de US [25] en Finland [26] aangetoond. Dit wordt op kleinere schaal bestudeerd in SLIM, de Study of Lifestyle Intervention and Impaired glucose tolerance Maastricht [27] [28]. Deze studie is geinitieerd binnen 
het AlO project van Marco Mensink en voortgezet binnen het onderzoek van Eva Corpeleijn en Cheryl Roumen. In dit onderzoek ontvingen personen met een gestoorde glucose tolerantie, een voorstadium van type 2 diabetes, vier maal per jaar een individueel advies van een dietiste om gezonder (minder vet) te gaan eten en meer te bewegen. Ook konden ze gratis deelnemen aan een bewegingsprogramma op de universiteit. De resultaten zijn bemoedigend. Hoewel slechts een beperkt gewichtsverlies bereikt werd, bleek dat gedurende de hele 5.5 jaar van het onderzoek de bloedsuikerspiegel sterk verbeterde in de interventiegroep, leidend uiteindelijk tot $40 \%$ minder ontwikkeling van diabetes. Deze verbetering bleek gepaard te gaan met een verhoogde verbranding van vetten door de spieren [29].

\section{SLIM van onderzoek naar praktijk}

Gezien de groeiende omvang van het probleem obesitas en diabetes is het van groot belang dat relevante onderzoeks resultaten vertaald worden naar de praktijk. Het SLIM onderzoek is niet alleen wetenschappelijk gezien interessant, het biedt ook aanknopingspunten voor preventie van diabetes in de praktijk van alledag. In samenwerking met de Unlversiteit van Wageningen en het RIVM zijn we een onderzoek aan het opstarten om dit te bewerkstelligen.

Het SLIM onderzoek is gebaseerd op algemeen geldende richtlijnen voor voeding en lichamelijke aktiviteit. Belangrijk hierbij is een advies op maat dat wil zeggen dat op basis van het individuele voedingspatroon en leefomgeving gekeken wordt hoe gezondheidswinst te bereiken. Binnen SLIM wordt ook gekeken welke factoren het succes op resultaat bepalen. Met deze informatie kunnen binnen de gezondheidszorg programma's afgestemd worden op subgroepen die kunnen verschillen in bijvoorbeeld sociaal-economische achtergrond, genetische achtergrond, ethniciteit en leeftijd.

Op zich zijn de resultaten van leefstijl studies eenduidig: gezond eten en meer bewegen is de meest effective manier om obesitas en diabetes tegen te gaan. In de praktijk blijkt die oplossing op individueel nivo niet zo simpel te realiseren, aangezien we bloot staan aan een omgeving die uitnodigt om veel te eten en weinig te bewegen. Overheid, bedrijfsleven, verzekeringsmaatschappijen, lokale beleidsinstanties, behandelaars en 
onderzoekers zullen afspraken moeten maken om leefstijladviezen op de meest effectieve manier te implementeren en om de 'dikmakende' omgeving te lijf te gaan. Dit enerzijds gezien de ernst van deze ziekten in relatie tot gezondheidscomplicaties en sterfte, en anderzijds gezien de torenhoge kosten die de voorziene stijging van deze ziekten met zich meebrengt. Er blijft op dit gebied nog veel werk te verzetten.

\section{Hoe nu verder?}

Voor de toekomst is het voor mij een grote uitdaging om mijn onderzoek in het Maastrichtse voort te zetten.

Binnen het humaan fysiologisch onderzoek komen steeds meer technieken beschikbaar die unieke mogelijkheden bieden om het vetmetabolisme in detail in het menselijk lichaam te bestuderen. Dit is een ontwikkeling die een belangrijke vooruitgang betekent in het inzicht hoe het vetmetabolisme gereguleerd wordt in gezondheid en ziekte. Daarnaast zijn er door snelle ontwikkelingen op het gebied van de moleculaire biologie technieken beschikbaar komen om processen op membraan/celnivo tot in detail te bestuderen Het zal een uitdaging zijn om de integratie tussen humaan fysiologisch onderzoek en moleculaire biologie verder te versterken. De onderzoeksfaciliteiten en de samenwerking tussen wat meer fundamentele onderzoeksgroepen en kliniek binnen Maastricht bieden unieke mogelijkheden om dit te bewerkstelligen, maar ook de samenwerking over stads- en landsgrenzen heen, zoals in Europese projecten, is hier zeer waardevol.

Naast de integratie van disciplines binnen het onderzoeksveld is het ook binnen het onderwijs een belangrijke missie om studenten het belang van het complete plaatje te laten zien naast de individuele onderdelen en componenten. Ik zelf ben als programmacoördinator nauw betrokken bij de relatief jonge studie richting moleculaire levenswetenschappen. In deze studierichting wordt de gezondheid en ziekte van de mens bestudeerd met name op moleculair nivo. Het metabolisme wordt bestudeerd op nivo van moleculen, genen, cellen, weefsels, lichaams- en populatie nivo. Deze richting gaat dan ook over de grenzen van disciplines heen, waardoor de vertaalslag van molecuul naar relevantie voor gezondheid en ziekte van de mens wordt gemaakt. In die zin is dit een richting die inspeelt op de ontwikkelingen binnen 
het onderzoeksveld. Ik denk dat voor deze studenten veel perspectief op de arbeidsmarkt zal zijn.

Over de grenzen van disciplines heengaan vereist de flexibiliteit om elkaars taal te leren spreken. Daarnaast is flexibiliteit binnen een dynamische organisatie belangrijk om de werkvloer de mogelijkheid te geven hun werkplaatsfunctie adequaat tot uiting te brengen. Ik spreek de hoop uit dat we gezamelijk bewerkstelligen dat deze aspecten in de toekomst nog meer gestalte gaan krijgen. Dus in meerdere opzichten is 'vet en gezondheid, een kwestie van flexibiliteit'. 


\section{Dankwoord}

Een heleboel mensen hebben bijgedragen aan het feit dat ik hier vandaag sta. Een aantal wil ik met name noemen:

Allereerst wil ik de Faculty of Health, Medicine and Life Sciences en het College van Bestuur van de Universiteit Maastricht van harte bedanken voor mijn benoeming en het in mij gestelde vertrouwen. Het is de voormalige Faculteit der Gezondheidswetenschappen die deze 'talentleerstoel' heeft ingesteld en ook een ontwikkel- en begeleidingstraject hieromheen heeft bewerkstelligd. Ik ben zeer blij met de mogelijkheden die mij hierdoor geboden zijn.

Wim Saris, beste Wim,

Jouw visie heeft aan de basis gestaan van veel onderzoek binnen NUTRIM. Bedankt voor alle mogelijkheden die je hebt gecreëerd om deze onderzoekslijn verder te ontwikkelen. Het pad is niet altijd over rozen gegaan, uiteindelijk heeft het 6 jaar geduurd waarin ik mijn eigen centen binnen moest halen voordat ik na mijn promotie die felbegeerde vaste aanstelling heb gekregen. Je hebt me die vaste baan niet in het vooruitzicht gesteld omdat er destijds gewoon geen mogelijkheden waren. Wel heb je door het in mij gestelde vertrouwen en je enthiousiasme mij altijd het gevoel gegeven dat het uiteindelijk wel zou lukken.

\section{Marleen van Baak, beste Marleen}

Onze start bij Humane Biologie viel nagenoeg samen. Tezamen hebben we vele technieken binnen het onderzoek opgezet en verder onwikkeld. Bedankt voor je kritische blik hierin, bedankt ook voor je altijd luisterend oor als ik soms meerdere malen per dag bij je binnen kwam vallen met weer nieuwe ideeën of soms preliminaire conclusies. Ik hoop dat we nog vele jaren de samenwerking voort kunnen zetten. En natuurlijk 30 november sta jij hier!

Collega's van de afdeling Humane Biologie

Dank voor de vaak prettige samenwerking!.

Uiteraard ben ik veel dank verschuldigd aan alle AlO's, post-docs, analisten en dietisten zonder wiens inspanningen ik hier vandaag niet gestaan had. Ik hoop in de toekomst de samenwerking met een veel teamspirit voort te kunnen zetten! 
Stabiele isotopen spelen een belangrijke rol in mijn onderzoek. Ik wil Jos en Annemie en alle mensen van SIRC van harte bedanken voor alle uitgevoerde analyses en ondersteuning. Luc, onze wegen in het onderzoek beginnen steeds meer te kruisen; ik hoop dat we deze samenwerking in de toekomst verder uit kunnen bouwen.

Met name wil ik nog Paul Schoffelen en Loek Wouters noemen. Bedankt voor alle hulp als ik weer eens in gevecht ben met mijn computer en voor het altijd inspringen bij een technisch mankement!

Ook de vele collega's binnen universiteit binnen de afdeling Interne Geneeskunde, Nucleaire Geneeskunde, Radiologie, Pulmonologie en GVO wil ik met harte bedanken voor de prettige en inspirerende samenwerking.

Buiten de stadsgrenzen wil ik met name Edith Feskens noemen, eerst bij het RIVM en nu bij de WU. Edith, onze samenwerking heeft wel bewezen wat integratie van disciplines op kan leveren. Ik hoop deze nog lang voort te mogen zetten.

De subsidiegevers van dit onderzoek, het Diabetes Fonds Nederland, de Nederlandse Organisatievan Wetenschappelijk onderzoek en de Europese Unie wil ik van harte danken voor de financiele ondersteuning.

Tenslotte, mijn famile. Veel dank ben ik verschuldigd aan mijn ouders die mij altijd in alles gestimuleerd hebben. Mijn vader heeft helaas veel niet meer mee kunnen maken, maar de herinnering aan zo'n fijne en stimulerende persoon is waardevol. Mama, bedankt voor het warme nest dat je over de jaren voor ons bent blijven creëeren waar we altijd een beroep op konden doen. Je bent een sterke, onafhankelijke vrouw maar bovenal een lieve moeder.

Lieve Jan-Paul, Lisa en Hannah,

De wetenschap kan heel mooi en inspirerend zijn, maar jullie laten me de werkelijk mooie dingen zien. Zonder jullie zou het niets betekenen.

Ik heb gezegd. 


\section{Literatuur}

1. Saxe JG. The blind men and the elephant. In The poetical works of John Godfrey Sax, Boston, MA: Houghton Mifflin.111-112. 1882.

2. Wild S, Roglic G, Green A, Sicree R, King H. Global prevalence of diabetes: estimates for the year 2000 and projections for 2030. Diabetes Care 2004, 27(5):1047-53.

3. Chakravarthy MV Booth FW. Eating, exercise, and "thrifty" genotypes: connecting the dots toward an evolutionary understanding of modern chronic diseases. J Appl Physiol 2004, 96(1):3-10.

4. Prentice AM, Rayco-Solon P, Moore SE. Insights from the developing world: thrifty genotypes and thrifty phenotypes. Proc Nutr Soc 2005, 64(2):153-61.

5. Warbrick-Smith J, Behmer ST, Lee KP, Raubenheimer D, Simpson SJ. Evolving resistance to obesity in an insect. Proc Natl Acad Sci U S A 2006, 103(38):14045-9.

6. Blaak EE, Hul G, Verdich C, Stich V, Martinez A, Petersen M, Feskens EF, Patel K, Oppert JM, Barbe P, Toubro S, Anderson I, Polak J, Astrup A, Macdonald IA, Langin D, Holst C, Sorensen TI, Saris WH. Fat oxidation before and after a high fat load in the obese insulin-resistant state. J Clin Endocrinol Metab 2006, 91(4):1462-9.

7. Astrup A, Ryan L, Grunwald GK, Storgaard M, Saris W, Melanson E, Hill JO. The role of dietary fat in body fatness: evidence from a preliminary meta-analysis of ad libitum low-fat dietary intervention studies. Br J Nutr 2000, 83 Suppl 1 (S25-32.

8. Saunders CL, Chiodini BD, Sham P, et al. Meta-Analysis of Genome-wide Linkage Studies in BMI and Obesity. Obesity (Silver Spring) 2007, 15(9):2263-2275.

9. Salonen JT, Uimari P, Aalto JM, et al. Type 2 diabetes whole-genome association study in four populations: the DiaGen consortium. Am J Hum Genet 2007, 81(2):338-45.

10. Kelley DE. Skeletal muscle fat oxidation: timing and flexibility are everything. J Clin Invest 2005, 115(7):1699-702.

11. Savage DB, Petersen KF, Shulman Gl. Mechanisms of insulin resistance in humans and possible links with inflammation. Hypertension 2005, 45(5):828-33.

12. Blaak EE Wagenmakers AJ. The fate of [U-(13)C]palmitate extracted by skeletal muscle in subjects with type 2 diabetes and control subjects. Diabetes 2002, 51(3):784-9.

13. Blaak EE. Basic disturbances in skeletal muscle fatty acid metabolism in obesity and type 2 diabetes mellitus. Proc Nutr Soc 2004, 63(2):323-30.

14. Blaak EE. Metabolic fluxes in skeletal muscle in relation to obesity and insulin resistance. Best Pract Res Clin Endocrinol Metab 2005, 19(3):391-403.

15. Corpeleijn E MM, Kooi ME, Roekaerts PMHJ, Saris WHM, Blaak EE. Impaired skeletal muscle substrate oxidation in glucose-intolerant men improves after weight loss. Obesity (Silver Spring) 2007, in press.

16. Blaak EE, Van Baak MA, Kemerink GJ, Pakbiers MT, Heidendal GA, Saris WH. Betaadrenergic stimulation of energy expenditure and forearm skeletal muscle metabolism in lean and obese men. Am J Physiol 1994, 267(2 Pt 1):E306-15. 
17. Blaak EE, Kemerink GJ, Pakbiers MT, Wolffenbuttel BH, Heidendal GA, Saris WH. Microdialysis assessment of local adipose tissue lipolysis during betaadrenergic stimulation in upper-body-obese subjects with type II diabetes. Clin Sci (Lond) 1999, 97(4):421-8.

18. Jocken JW, Langin D, Smit E, Saris WH, Valle C, Hul GB, Holm C, Arner P, Blaak EE. Adipose triglyceride lipase and hormone-sensitive lipase protein expression is decreased in the obese insulin-resistant state. J Clin Endocrinol Metab 2007, 92(6):2292-9.

19. Ryden M, Jocken J, van Harmelen V, Dicker A, Hoffstedt J, Wiren M, Blomqvist L, Mairal A, Langin D, Blaak E, Arner P. Comparative studies of the role of hormone-sensitive lipase and adipose triglyceride lipase in human fat cell lipolysis. Am J Physiol Endocrinol Metab 2007, 292(6):E1847-55.

20. Bickerton AS, Roberts R, Fielding BA, Hodson L, Blaak EE, Wagenmakers AJ, Gilbert M, Karpe F, Frayn KN. Preferential uptake of dietary Fatty acids in adipose tissue and muscle in the postprandial period. Diabetes 2007, 56(1):168-76.

21. Halaas JL, Gajiwala KS, Maffei M, Cohen SL, Chait BT, Rabinowitz D, Lallone RL, Burley SK, Friedman JM. Weight-reducing effects of the plasma protein encoded by the obese gene. Science 1995, 269(5223):543-6.

22. Cordain L, Eaton SB, Miller JB, Mann N, Hill K. The paradoxical nature of huntergatherer diets: meat-based, yet non-atherogenic. Eur J Clin Nutr 2002, 56 Suppl 1 (S42-52.

23. Cordain L, Watkins BA, Florant GL, Kelher M, Rogers L, Li Y. Fatty acid analysis of wild ruminant tissues: evolutionary implications for reducing diet-related chronic disease. Eur J Clin Nutr 2002, 56(3):181-91.

24. Eaton SB, Eaton SB, 3rd, Sinclair AJ, Cordain L, Mann NJ. Dietary intake of longchain polyunsaturated fatty acids during the paleolithic. World Rev Nutr Diet 1998, 83(12-23.

25. Knowler WC, Barrett-Connor E, Fowler SE, Hamman RF, Lachin JM, Walker EA, Nathan DM. Reduction in the incidence of type 2 diabetes with lifestyle intervention or metformin. N Engl J Med 2002, 346(6):393-403.

26. Tuomilehto J, Lindstrom J, Eriksson JG, Valle TT, Hamalainen $H$, Ilanne-Parikka P, Keinanen-Kiukaanniemi S, Laakso M, Louheranta A, Rastas M, Salminen V, Uusitupa M. Prevention of type 2 diabetes mellitus by changes in lifestyle among subjects with impaired glucose tolerance. N Engl J Med 2001, 344(18):1343-50.

27. Mensink M, Feskens EJ, Saris WH, De Bruin TW, Blaak EE. Study on Lifestyle Intervention and Impaired Glucose Tolerance Maastricht (SLIM): preliminary results after one year. Int J Obes Relat Metab Disord 2003, 27(3):377-84.

28. Mensink, M. Blaak, E. E., Corpeleijn, E., Saris, W. H., de Bruin, T. W. Feskens, E. J. Lifestyle intervention according to general recommendations improves glucose tolerance. Obes Res 11(12); 1588-96, 2003.

29. Mensink M, Blaak EE, Wagenmakers AJ, Saris WH. Lifestyle intervention and fatty acid metabolism in glucose-intolerant subjects. Obes Res 2005, 13(8):1354-62. 
